\title{
«In Every Music There is Bach...». Music as a Subject of Theology
}

\author{
Archpriest Alexander Zadornov \\ $\mathrm{PhD}$ in Theology \\ Head at the Department of Church Practical Disciplines \\ at the Moscow Theological Academy \\ Holy Trinity-St. Sergius Lavra, Sergiev Posad 141300, Russia \\ azadornov@yandex.ru
}

For citation: Zadornov, Alexander V., archpriest. "«In Every Music There is Bach...». Music as a Subject of Theology”. Praxis, 2020. № 3 (5), 2020, pp. 214-219 (in Russian). DOI: 10.31802/ PRAXIS.2020.5.3.016.

\begin{abstract}
The article considers publications of recent years devoted to the religious content of the work of I. S. Bach. The classic of world music appears as a religious composer, his works as theological works. An attempt was made to analyze the idea of Bach in the light of the phenomenological analysis of music by the Russian religious philosopher A. F. Losev. Losev's desire for «pure music» appears as the antithesis of Bach's expressiveness, which is rooted precisely in his religious worldview, given in the tradition of Lutheranism. The article also reviews D. E. Gardiner's monograph «Music in Heavenly Grad. Portrait of Johann Sebastian Bach» and Russian translations of texts of spiritual works by the German composer. It is concluded that the reasons for the popularity of Bach's religious works are evidence of a post-secular assessment of his work.

Keywords: Church music, lutheranism, I. S. Bach, A. F. Losev, J. E. Gardiner, hegumen Peter (Meshcherinov).
\end{abstract}

\section{References}

Gardiner D. Ė. (2019) Muzyka v Nebesnom Grade. Portret Ioganna Sebastiana Bakha [Music in the Heavenly City. Portrait of Johann Sebastian Bach]. Moscow: Rosebud Publishing (in Russian).

Losev A. F. (1995) “Muzyka kak predmet logiki” [“Music as a Subject of Logic”], in Forma-Stil’Vyrazhenie [Form-Style-Expression]. Moscow: Mysl', pp. 405-602 (in Russian).

Meshcherinov P. (2014) Dukhovnye kantaty Ioganna Sebast'iana Bakha [Spiritual Cantatas by Johann Sebastian Bach], available at: https://pravmir.ru/igumen-pyotr-meshherinovduhovnyie-kantatyi-ioganna-sebastyana-baha-lektsiya (01.12.2020) (in Russian).

Meshcherinov P. (2015) Iogann Sebast'jan Bakh. Bogoslovie v zvukakh [Johann Sebastian Bach. Theology in Sounds], available at: https://pravmir.ru/igumen-petr-meshherinov-iogannsebastyan-bax-bogoslovie-v-zvukax (01.12.2020) (in Russian).

Meshcherinov P. (2019) Bach I. S. Texts of spiritual works: all the works of the great master [Bach I. S. Texts of Spiritual Works: All the Works of the Great Master]. Moscow: Eksmo (in Russian).

Nasonov R. Bah dlja zhizni i smerti [Bach for Life and Death], available at: https://gorky.media/ context/bah-dlya-zhizni-i-smerti (дата обращения: 01.12.2020) (in Russian). 


\title{
РОЛЬ ЖЕНЩИН В ЦЕРКВИ И ВОЗМОЖНОСТЬ ИХ РУКОПОЛОЖЕНИЯ В СОВРЕМЕННЫХ ЗАРУБЕЖНЫХ И РОССИЙСКИХ ИССЛЕДОВАНИЯХ
}

\author{
Андрей Александрович Зотин \\ аспирант кафедры церковно-практических дисциплин \\ Московской духовной академии \\ 141300, Московская область, Сергиев Посад \\ Троице-Сергиева Лавра, Академия \\ zotin_andreyy@rambler.ru
}

Для цитирования: Зотин А. А. Роль женщины в церкви и возможность их рукоположения в современных зарубежных и российских исследованиях // Праксис. 2020. № 3 (5). С. 220-226. DOI: 10.31802/PRAXIS.2020.5.3.017.

\section{Аннотация}

УДК 348.07

В представленном обзоре рассматриваются недавно изданные протоколы и стенограммы Поместного Собора 1917-1918 гг. а также исследование протестантского богослова Вильфрида Херле посвящённые роли женщины в Церкви и возможности ее рукоположения на основании Священного Писания. Сравниваются православный и протестантский взгляды по этому вопросу Анализируются и критикуются методологические предпосылки протестантского подхода.

Ключевые слова: ординация, женское священство, роль женщины в Церкви, Священный Собор Православной Российской Церкви 1917-1918 гг., Вильфрид Хэрле. 


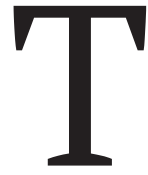

ема возможного рукоположения женщины в священный сан, являясь частью развивающейся протестантской феминистской теологии, в последние годы притягивает все больший интерес зарубежных и отечественных исследователей. Связано это прежде всего с некоторыми очевидными причинами, одна из которых увеличение присутствия женщины в церковной жизни и попытки нахождения канонического богословско-библейского выверенного ее статуса и положения сегодня. В протестантских деноминациях идея рукоположения женщины в священный сан уже реализовалась и имеет ряд оснований в Священном Писании.

В этой связи открывается перспектива для необходимости богословского осмысления и поиска ответов с позиций православного богословия. Одной из причин вызванной необходимости является тот факт, что ни в Священном Писании, ни в канонах Церкви действительно нет однозначного ответа на вопрос о том, может ли женщина быть рукоположена в священный сан или категорически не может. Единственным критерием ответа и камнем преткновения в этом вопросе среди протестантских и православных исследователей служит интерпретация текстов Священного Писания и, как следствие, конструкция выводов.

Такое поле, в основании которого находится интерпретация текста Священного Писания и вызывает полемику, свидетельством чему является издание книги одного из крупнейших современных протестантских богословов Хэрле Витфрида «По поручению Христа? Рукоположение женщин: pro et contra», перевод которого вышел в 2020 г. Исследование состоит из пяти глав, в которых автор подробно разбирает библейские аргументы «за» и «против» рукоположения женщины.

Первая глава - об отношениях между мужчиной и женщиной с библейско-христианской точки зрения - содержит сведения о мужчине и женщине в библейских высказываниях о творении, после грехопадения, о мужчине и женщине в Иисусе Христе. Автор, приводя и анализируя отрывки из повествования Бытописателя о жизни первых людей до грехопадения и после делает вывод, что «с точки зрения обоих библейских рассказов о творении все говорит в пользу равенства (не одинаковости!) мужчины и женщины» ${ }^{1}$, «согласно ясным словам Библии, главенство мужчины над женщиной (или подчинение женщины мужчине) - это не часть Божьего порядка творения, а его нарушение вследствие греха»². С данными выводами невозможно согласится. Вероятно, 
автор опирается теорию Моргана и Энгельса о патриархате и в соответствии с ней делает выводы касательно интерпретации текста. Кроме этого, Священное Писание вполне очевидно говорит о том, что мужчина и женщина между собой не равны в иерархическом смысле.

Вторая глава посвящена анализу библейских высказываний о женском служении делу проповеди Слова Божьего. Третья глава посвящена лютеровской теории всеобщего священства и ее историческому развитию.

Особый интерес вызывает четвертая глава о возможности рукоположения женщины. Автор отмечает, что для пастырского служения пригодны не все христиане, но необходимы дополнительные качества, обобщая которые он называет «богословской компетентностью». Под этим термином разумеется способность в свете христианской вести понимать церковное служение, распознавать свои задачи в настоящее время, а также планировать их конкретное выполнение. Следовательно, если женщина обладает данным компонентом, то она вполне может быть возведена в священническую степень, к выводу, о чем и приходит: «Истина, гласящая, что во Христе нет ни иудея, ни эллина, ни раба, ни свободного, ни мужчины, ни женщины, показывает, какие человеческие свойства нельзя делать критерием при допущении к рукоположению. Бытие во Христе включает в себя бытие с женщиной так же, как бытие с греком, и бытие рабом - так же, как бытие свободным. Наши размышления можно подытожить следующим образом: если крещеный член общины имеет все предпосылки для поставления на пасторское служение, то отказ ему в рукоположении на пасторское служение по причине ли того, что этот член общины еврей, или грек (то есть не еврей), или раб, или свободен, или мужчина, или женщина, будет несовместим с сущностью и поручением христианской Церкви» ${ }^{3}$.

Однако следует высказать несогласие с выводом, приведенным автором, по той причине, что в пассаже 3.28 из Послания к Галатам, на основании которого и делается главный довод о возможности рукоположения женщины, говорится прежде всего о равенстве перед Богом. О равенстве в нравственном отношении, а не в отношении иерархическом, материальном или правовом. Это подтверждается самим апостолом Павлом, когда, говоря о равенстве, Павел в Послании к Римлянам (Рим. 3, 1-2) выделяет первенствующую роль и преимущество иудея. Затем в $(1$ Кор. 7,21$)$ он же повествует о том, что положение свободного 
гражданина выше, чем положение раба. Если продолжать развивать данную мысль, то очевидна разница между ученым и неучем, и т. д., однако все люди равны перед Богом в нравственном отношении. Но о равенстве иерархического порядка речи не идет.

Далее, исходя из идеи равенства во Христе, в этой же главе В. Хэрле пишет, что в церквях люди попросту привыкли видеть в роли священника мужчину, а женщины, уже давно имеющие возможность получать образование и права принимать небольшое участие в жизни общины и церкви, устали слушать призывы к терпению. Другими словами, в том, что женщина не может получить рукоположение, автор видит социальные причины и предлагает признать церкви вину в том, что «такой настрой был основан на общепринятом недопущении женщин к качественному образованию, за которое долю ответственности несут христианские церкви. В этом отношении недопущение женщин к рукоположению и пасторскому служению остается следствием нарушений общественного развития» ${ }^{4}$.

В этой связи стоит сказать, что не социальные причины не допускают женщину к хиротонии, а антропологический аргумент. Христианство, наоборот, возвысило женщину. Она в первые века христианства занимала почетное положение в церковном обществе и клире. Существовавшие в первые века христианства диакониссы были тому подтверждением. По аналогии с Богом установленной иерархией отношений, диакониссы входили в клир и занимали почетную церковнослужительскую степень и были помощницами диакону, священнику и епископу, как жена для мужа. Поэтому в православной традиции женское священство неприемлемо.

В связи с этим особое внимание обращает на себя издание стенограмм и докладов и фрагментов соборных дискуссий Поместного Собора 1917-1918 гг. о роли женщины в Церкви, вышедшей в свет в 2020 г.

Книга содержит итоговые документы Поместного Собора по вопросу роли женщин в церковной жизни, такие как «О привлечении женщин к деятельному участию на разных поприщах церковного служения», «Об участии женщины в жизни Церкви», «О праве женщины входить в алтарь», «О восстановлении чина диаконисс».

Структура издания выстраивается по тематическому порядку. Первая глава посвящена предварительным обсуждениям вопроса о роли женщины в Церкви как на пленарных заседаниях, так и на заседаниях Отдела о церковной дисциплине. 
Вторая глава отражает подробное рассмотрение вопроса о роли женщины в Церкви в Отделе о Церковной дисциплине. Описывает сообщение докладчика Отдела по этому вопросу, прения участников и итоговую резолюцию, выносимую на Собор.

Третья глава издания содержит доклад Отдела о церковной дисциплине «Об участии женщин в жизни Церкви» на третьей сессии Поместного Собора 1917-1918 гг. дискуссии участников касательно содержания доклада, обсуждения поправок, адресуемых к докладу.

Четвертая глава называется «Дела, возникшие при разработке на Соборе “Женского вопроса”» и включает в себя сведения об обсуждении вопроса восстановления чина диаконисс, доклад, составленный священномучеником митрополитом Владимиром (Богоявленским), а также вопросы о праве женщины входить в алтарь, возможность принимать участие в церковном управлении и быть старостами.

Обсуждение Поместным Собором темы восстановления института диаконисс представляется чрезвычайно важной и интересной в контексте сопоставления идей и взглядов на роль и место женщины в Церкви представителей протестантской феминистской теологии и участников Поместного Собора 1917-1918 гг. Так, доклад, автором которого является священномученик митрополит Владимир (Богоявленский), указывает на необходимость восстановления существовавшего ранее в Церкви чина диаконисс: «Переживаемое нами время в положении Церкви, некоторыми чертами напоминающее первые века христианства, побуждает вспомнить о полезном служении диаконисс в Древней Церкви, призвать верующую русскую женщину к особливому служению ее Церкви в звании диакониссы» ${ }^{5}$.

Далее, исходя из иерархического понимания Божьего порядка и положения женщины, митрополиту Владимиру, да и всем членам Отдела о церковной дисциплине, которые единогласно высказались за восстановление этого древнего чина, в голову не приходит сопоставить недостаток образованности женщины как причину, по которой они не могли получить рукоположение. Однако наоборот, основываясь на Священном предании Церкви, в докладе указывается, что «в Русской Православной Церкви учреждается чин диаконисс применительно к тому виду, в каком он существовал Древней Церкви» ${ }^{6}$. 
Кроме этого, непосредственный интерес вызывает приложение к данному докладу в виде предлагаемого чинопоследования поставления диаконисс, согласно которому над ставленницей во диакониссу производилась хиротония в алтаре 7 .

Пятая глава издания посвящена отдельным соборным дискуссиям и высказываниям соборян, касающихся роли женщины в Церкви. О допущении женщины к учительству и делу проповеди, о роли женщины на приходе, об участии женщины в деле просвещения и миссии, а также о возрасте монашеского пострига для женщины.

Подытоживая, издание стенограмм Поместного Собора 1917-1918 гг. о роли женщины в Церкви производит крайне благоприятное впечатление. Интереснейшие и различные по характеру дискуссии и мнения соборян Отдела о церковной дисциплине единодушно сходятся в том, что женщину нужно допустить к активному участию в жизни Церкви, расширить круг церковной деятельности женщины, восстановить институт диаконисс, так как это принесет большую пользу для жизни церковной.

\title{
Библиография
}

Вильрид Х. По поручению Христа? Рукоположение женщин: pro et contra. М.: Библейскобогословский институт, 2020.

Священный Собор Православной Российской Церкви 1917-1918 гг. о роли женщин в Церкви / предисловие А. И. Мраморнова. М.: Спасское дело, 2020.

\section{The Role of Women in the Church and the Possibility of their Ordination in Modern Foreign and Russian Studies}

\author{
Andrey A. Zotin \\ PhD student \\ at the Department of Church Practical Disciplines \\ at the Moscow Theological Academy \\ Holy Trinity-St. Sergius Lavra, Sergiev Posad 141300, Russia \\ zotin_andreyy@rambler.ru
}

For citation: Zotin, Andrey A. "The Role of Women in the Church and the Possibility of their Ordination in Modern Foreign and Russian Studies”. Praxis, № 3 (5), 2020, pp. 220-226 (in Russian). DOI: 10.31802/PRAXIS.2020.5.3.017.

7 Священный Собор Православной Российской Церкви 1917-1918 гг. о роли женщин в Церкви. С. 24. 
Abstract. This review examines the recently published minutes and transcripts of the Local Council of 1917-1918. as well as a study by the Protestant theologian Wilfried Herle devoted to the role of women in the Church and the possibility of her ordination on the basis of Holy Scripture. The Orthodox and Protestant views on this issue are compared. Methodological premises of the Protestant approach are analyzed and criticized.

Keywords: ordination, female priesthood, the role of women in the Church, the Holy Council of the Russian Orthodox Church 1917-1918, Wilfried Haerle.

\section{References}

Mramornov A. I. (ed.) (2020) Svjashhennyj Sobor Pravoslavnoj Rossijskoj Cerkvi 1917-1918 gg. o roli zhenshhin v Cerkvi [The Holy Council of the Orthodox Russian Church 1917-1918 on the Role of Women in the Church]. Moscow: Spasskoe delo (in Russian).

Vil'rid X. (2020) Po porucheniju Hrista? Rukopolozhenie zhenshchin: pro et contra [On Behalf of Christ? Ordination of Women: Pro et Contra]. Moscow: Biblejsko-bogoslovskij institute (in Russian). 